\title{
Children's Books and Literature from the Perspectives of Preschool and Primary Teachers
}

\author{
Vera Lúcia Correia Mota \\ Master in Preschool and Primary Education \\ University of The Azores, Portugal
}

\author{
Ana Isabel Santos \\ University of The Azores, Faculty of Social Sciences and Humanities, \\ Interdisciplinary Centre for Childhood and Adolescence - NICA - UAc, Portugal \\ CIE - ISPA - Instituto Universitário

\section{Maria Madalena Teixeira da Silva} \\ University of The Azores, Faculty of Social Sciences and Humanities, \\ Interdisciplinary Centre for Childhood and Adolescence - NICA - UAc, Portugal
}

Doi: 10.36941/jesr-2020-0oo4

\section{Abstract}

This paper seeks to understand how a group of preschool and primary teachers perceive the type of use they carry out of children's literature. Thus, it analyses the type of books in the classrooms and the underlying criteria for their choice, the frequency of the activities implemented within this scope and the organisation of the educational environment for the promotion of reading skills. In terms of the methodology used, this research is based on the collection of information through a questionnaire survey, completed by 24 preschool teachers and 53 primary teachers of S. Miguel Island, The Azores, Portugal. The data collected were analysed both quantitatively and qualitatively. The data allow concluding that, although all respondents value children's literature, there are differences between the way preschool and primary teachers use it, alerting to the need for deeper reflection on the pedagogical practices implemented.

Keywords: children's literature, preschool education, primary education.

\section{Context of the Study}

Currently, we know that, from an early age, children are in contact with writing in their contexts of action and that, also from an early age, this contact with the world of writing allows them to build conceptions about its functions, use and the rules that underlie it (Alves Martins \& Niza, 1998; Santos, 2007). For this to happen, it is critical that adults who live with them be aware of their role in promoting and enhancing rich writing learning contexts, given that, as stated by Chambers (1996), "readers are made by readers" (p. 78).

In formal educational contexts, it is up to preschool and primary teachers to increase reading habits, helping to understand the various functions of reading, preparing moments of reading 
promotion and gearing school and extra-school reading. Anyhow, these moments must be preceded by the organisation and selection of spaces, readings and literary texts, according to the children's age and interests (Cerrillo, 2006).

Thus, in the first place, it is central, in the classroom/classroom context, to organise spaces for reading, taking into account not only their location in the available physical space but especially factors such as the variety of books and printed materials and the diversity of other reading materials, including technological ones (Dynia et al., 2018). This relationship between the organisation of reading-oriented spaces, usually named classroom/activities' room library areas, there is a longstudied and proven direct relationship between the quantity and quality of the materials, the physically inviting environment and children's involvement in reading behaviours (Morrow, 1982; Morrow \& Weinstein, 1982). Some key elements in bringing the child closer to reading are, among others, placing this area in a warm and bright place, with equipment that enables children's access to reading materials comfortably, and carefully organising reading materials (books of different sizes and literary genres, with more or less illustrations, aimed at different development levels and interests and meaningful to children) (Morrow \& Gambrell, 1998; Rueda, 1995; Hayes, 2016).

The way how these materials are used, especially in the implementation of specific strategies by preschool and primary teachers, which allow the child to find, on their exploration, diverse functions and multiple reasons for wanting to read, is equally important (Sénéchal, 2006; Santos, 2007; Guo, Justice, Kaderavek, \& McGinty, 2012). The material rotation, the design and implementation of activities specifically geared towards the book and children's literature planned by preschool and primary teachers, the establishment of moments that allow the use of spaces devoted to reading when children show interest, and activities that enhance the joint construction of learning in this domain are conditions that add effectively to the creation of personal reader projects, provided that they take place with regularity and systematically (Chambers, 1996; Alves Martins \& Niza, 1998; Santos, 2007; Hayes, 2016).

However, we should not forget that the definition and implementation of these strategies are directly related to preschool and primary teachers' initial and continuous training, attitudes and conceptions regarding learning processes in general (Levitt \& Red Owl, 2013) and, in particular, the processes of the development and learning of reading skills in children (Wray, Medwell, Fox, \& Poulson, 2000; Santos, 2007; Lim, 2010; Brown, Scull, Nolan, Raban, \& Deans, 2012; Bingham \& HallKenyon, 2013). These aspects should be considered in the analysis and understanding of the educational environment and in the way how pedagogical actions fostering literacy are thought and implemented, in a proactive logic of improvement of the conditions that are offered to children and young people in formal educational contexts.

Within these spaces and their diversity, the reading of literary texts should be "a significant and repeated practice [...] at all levels of education, since it favours critical thinking, arouses the child's interest and taste for the beauty of poetic language and the discovery of meanings entailed in the text" (Mergulhão, 2011, p. 2). Among the many tasks that preschool and primary teachers propose to develop, the promotion of reading and books is undoubtedly critical in their pedagogical action, namely in the use of children's literature as a tool that allows the reader to develop his/her imagination, accessing a unique knowledge of the world and broadening the way he/she sees it (Palo \& Oliveira, 1992; Azevedo, 2006; Terwagne, 2006). Regarding the selection of works that are suitable for children, the general tendency of scholars in this field is to resort, as Isabel Tejerina Lobo (2004, para. 3) ascertains, to a mixing of criteria, among which the most important would be "the aesthetic model they provide, their significance in the history of Humanities, the values they convey, the subject they deal with and the identification they enable with child and teenager readers". The adequacy of the context of the promotion of reading to the understanding of readers in training and its representativeness in terms of the literary tradition is also important. In turn, Teresa Colomer (2002) selects four determining aspects: the literary quality, the educational values, the children's opinion and taste, and the step of their evolution in terms of training for the reading.

In turn, Silva (2013) maintains that the aforementioned criteria should dialogue with each other 
in a model that is based mainly on the interactive relationship between the main strands of a literary work. Thus, the author argues that the aesthetic/literary quality enriches the vision of the world that it creates, at the same time that it depends on it. This interdependence relationship also encompasses the resources used in the form of expression and the possibilities of critical reading offered.

Silva (2013) summaries the various standpoints on the contribution of literature to the readers' development in the following way:

- develop the language competence and thereby improve the ability to understand the world, which human beings mostly internalise and express through language;

- diversify the knowledge of the world and life experiences, broadening the responsiveness to new situations, but also, and above all, developing the ability to accept and/or understand the difference;

- improve self-awareness in the face of the otherness that forces to reflect and measure inner dimension and complexity;

- build a sense of belonging to a more or less restricted community, agreeing with its paradigmatic values - ultimately, with the essential nature of the human being;

- select, from all the knowledge offered by literature, the one that best meets personal individuality, participating attentively and critically in the dialogue it proposes;

- freely appreciate the aesthetic pleasure offered by literary art.

Thus, children's literature, while providing, above all, an enriching aesthetic experience in terms of the verbal and iconic text, is also rich in feelings and emotions. Furthermore, it also conveys norms of social coexistence, such as respect for the other and attitudes of solidarity and commitment.

Thus, and as the role of preschool and primary teachers in the organisation and management of the spaces devoted to reading is fundamental in the promotion of reading behaviours, we will analyse the way the teachers of these two educational levels claim to use children's literature in their pedagogical practice. To this end, the type of books they report having in their classrooms and the underlying criteria for their choice, the frequency of the activities implemented in this area and the organisation of the educational environment for the promotion of reading skills are examined.

\section{Methodological Options}

In methodological terms, this study results from the collection of information through a questionnaire survey. The choice for this type of instrument was related to the fact that it is "[...] a procedure for exploring ideas and general beliefs about some aspect of reality" (Gómez, Flores, \& Jiménez, 1996, p.185), which allows the attainment of a broad view of how teachers view their pedagogical practices.

The questionnaire for preschool and primary teachers was identical and consisted of fourteen questions, grouped into two parts. The first part allowed collecting information on the demographic features of respondents, namely gender, profession and length of service. The second part focused on how teachers claim to use children's literature in the activities' room/classroom. It included aspects such as (i) the importance of using children's literature in their classroom; (ii) how often they do it; (iii) the criteria for the selection of the books; (iv) the space where they are made available; (iv) the regularity with which they are changed; (v) the frequency of the activities promoted based on them; (vi) the regularity with which students use this space; (vii) the types of books found there; and (viii) the features of the area where the books are located.

The questionnaire is mostly composed of closed-response questions (ten), given that this study aimed to obtain a broader view of how children's literature is developed in the respondents' classroom. Open-ended questions, although fewer (only four), were sufficient to deepen the importance ascribed by preschool and primary teachers to children's literature.

In total, 120 questionnaires were delivered and 77 were completed. The questionnaires were distributed in fifteen schools from the public school system of São Miguel Island, the Azores, 


\section{Portugal.}

The data collected from the questionnaire surveys were analysed quantitatively through the SPSS statistical analysis program. Furthermore, they were analysed qualitatively through the content analysis technique of open questions, inasmuch that, as stated by Bogdan and Biklen (1994), "data analysis is the systematic process of searching and organising [...] to increase one's understanding of these materials, enabling him/her show others what he/she has found" (p. 205).

\section{Teachers' Perspectives on the Book and Children's Literature in Preschool and Primary Education}

\subsection{Participants' characterisation}

77 teachers participated in this study, being 24 female preschool teachers and 53 primary teachers (henceforth referred to as primary teachers), 48 of whom were female (90.6\%), and 5 were male (9.4\%). Participants had diverse school backgrounds.

Concerning the respondents' professional experience, most preschool teachers have more than 21 years of service (33.3\% have between 21 and 25 years of service, and 33.3\% have over 25 years); $33.4 \%$ have between 10 and 20 years of service, with no record below 10 years, which allows stating that this is a group of teachers with substantial experience.

\subsection{The Book and Children's Literature from the perspective of Preschool and Primary Teachers}

\subsubsection{The Importance of Children's Literature}

Participants' answers regarding the importance of using children's literature allowed identifying two subcategories: the development of competences and literature as a Common Good. For $70.8 \%$ of the preschool teachers, children's literature is important because it promotes the development of reading and oral language, whereas, for primary teachers, its importance is linked to the development of lexical and semantic competences (49.1\%). Ten (41.7\%) of the preschool teachers who participated in the study stated that literature is important because it is a source of knowledge which also develops creativity (37.5\%), increases critical thinking (33.3\%) and develops written language and lexical and semantic competences (20.8\%). $16.7 \%$ of these participants see it as a healthy habit and $12.5 \%$ state that it is important because it is transversal to all areas.

Regarding the primary teachers who participated in the study, $47.2 \%$ envisage literature as a means of promoting creativity, $37.7 \%$ stated that it develops reading/oral language, $34 \%$ ascribed the importance of literature also to written language, $30.2 \%$ to the development of critical thinking, $28.3 \%$ to the fact that it is a source of knowledge, $7.5 \%$ to being a healthy habit and $1.9 \%$ to being transversal to all areas.

\subsubsection{Strategies for the Organisation and Management of Reading Spaces in the activities' room/classroom}

Regarding the organisation of the activities' room/classroom space, first and foremost, it should be noted that not all participants claim to have a space devoted to reading and the privileged use of children's literature. While it is true that all preschool teachers state that they have a library corner or a reading area in the room, of the 53 teachers surveyed, ten said that they have no room for books and the remaining 43 stated that they have a shelf or bookcase that fulfils this purpose.

When asked about the type of books that can be found in their classroom libraries or reading spaces, data allow concluding that regarding preschool teachers, the most common types of writing media are thematic books ( $83.4 \%$ for the categories "many" and "some"), newspapers and magazines (79.1\% for the categories "many" and "some"), children's literature books $(77.8 \%$ for the categories 
"many" and "some") and word files (58.3\% for the categories "many" and "some"). Dictionaries and encyclopaedias seem to be less frequent (see Table 1). Oddly, $22.2 \%$ of preschool teachers reported having few or no books on children's literature.

Table 1. Types of books in the Library Area in Preschool Education

\begin{tabular}{|l|l|c|c|c|c|}
\cline { 3 - 6 } \multicolumn{2}{c|}{} & \multicolumn{4}{|c|}{ Preschool teachers } \\
\cline { 3 - 6 } \multicolumn{2}{c|}{} & $\begin{array}{c}\text { Many } \\
(\%)\end{array}$ & $\begin{array}{c}\text { Some } \\
(\%)\end{array}$ & $\begin{array}{c}\text { Few } \\
(\%)\end{array}$ & $\begin{array}{c}\text { None } \\
(\%)\end{array}$ \\
\hline \multirow{3}{*}{$\begin{array}{l}\text { Types of books in the } \\
\text { library area }\end{array}$} & Encyclopaedia & $8.3 \%$ & $20.8 \%$ & $33.3 \%$ & $37.5 \%$ \\
\cline { 2 - 6 } & Dictionary & $0.0 \%$ & $16.7 \%$ & $37.5 \%$ & $45.8 \%$ \\
\cline { 2 - 6 } & Word files & $12.5 \%$ & $45.8 \%$ & $33.3 \%$ & $8.3 \%$ \\
\cline { 2 - 6 } & Thematic books & $16.7 \%$ & $66.7 \%$ & $8.3 \%$ & $8.3 \%$ \\
\cline { 2 - 6 } & Children's literature & $36.1 \%$ & $41.7 \%$ & $15.3 \%$ & $6.9 \%$ \\
\cline { 2 - 6 } & Newspapers and magazines & $20.8 \%$ & $58.3 \%$ & $12.5 \%$ & $8.3 \%$ \\
\hline
\end{tabular}

For the primary teachers who participated in the study, the most common types of writing media are children's literature books ( $84.2 \%$ for the categories "many" and "some"), thematic books (71.7\% for the categories "many" and "some"), newspapers and magazines (64.2\% for the categories "many" and "some") and dictionaries (60.4\% for the categories "many" and "some"). Word files and encyclopedias seem to be less frequent (see Table 2).

Table 2. Types of books in the Library Area in the Primary Education

\begin{tabular}{|l|l|c|c|c|c|}
\cline { 3 - 6 } \multicolumn{2}{c|}{} & \multicolumn{4}{|c|}{ Primary Teachers } \\
\cline { 3 - 6 } \multicolumn{2}{c|}{} & $\begin{array}{c}\text { Many } \\
\text { (\%) }\end{array}$ & $\begin{array}{c}\text { Some } \\
(\%)\end{array}$ & $\begin{array}{c}\text { Few } \\
(\%)\end{array}$ & $\begin{array}{c}\text { None } \\
(\%)\end{array}$ \\
\hline \multirow{4}{*}{$\begin{array}{l}\text { Types of books in the } \\
\text { library area }\end{array}$} & Encyclopaedia & $1.9 \%$ & $18.9 \%$ & $35.8 \%$ & $43.4 \%$ \\
\cline { 2 - 6 } & Dictionary & $3.8 \%$ & $56.6 \%$ & $24.5 \%$ & $15.1 \%$ \\
\cline { 2 - 6 } & Word files & $3.8 \%$ & $28.3 \%$ & $22.6 \%$ & $45.3 \%$ \\
\cline { 2 - 6 } & Thematic books & $13.2 \%$ & $58.5 \%$ & $18.9 \%$ & $9.4 \%$ \\
\cline { 2 - 6 } & Children's literature & $31.4 \%$ & $52.8 \%$ & $11.9 \%$ & $3.8 \%$ \\
\cline { 2 - 6 } & Newspapers and magazines & $17 \%$ & $47.2 \%$ & $18.9 \%$ & $17.0 \%$ \\
\hline
\end{tabular}

Besides knowing the types of books available, it is also important to explore how they are exposed in the room, their amount and diversity of format, and the levels of development they are intended for. Thus, when asked how these books are exposed, $87.5 \%$ of preschool teachers stated that they have them in the front, so that the child sees the cover, whereas only $66.0 \%$ of primary teachers reported that they have them in this position.

Concerning the number of books, both preschool and primary teachers stated that they have enough books for their students (79.2\% of preschool teachers and $79.2 \%$ of primary teachers). Only $20.8 \%$ of preschool teachers and $20.8 \%$ of primary teachers claimed that they do not have enough books in their class.

In terms of the format of the existing books, all preschool teachers and a high percentage of primary teachers $(96.2 \%)$ stated that they have books of different sizes and formats in their classrooms.

Moreover, the diversity of books also emerges as a constant. For $94.3 \%$ of the primary teachers, there are several books in their classroom, and so it is for $88.3 \%$ of the preschool teachers.

Finally, and to assess if this diversity respects the needs of children attending these activities' rooms/classrooms, participants were asked whether the existing books were directed at different levels of development. Over 90.0\% of both preschool and primary teachers answered affirmatively to this question, and $8.3 \%$ and $5.7 \%$ of preschool and primary teachers, respectively, answered that they had no books directed for different levels of development. 


\subsubsection{Strategies for Using the Book and Children's Literature}

When asked about whether they use or not children's literature books in their pedagogical practices, all respondents were unanimous in stating they use it as a pedagogical tool, which, in the case of preschool teachers, seems to be more frequent.

Thus, $87.5 \%$ of preschool teachers stated that they use children's literature books daily, and the remaining $12.5 \%$ said that they do it weekly. Hence, there are no preschool teachers who do it only monthly, contrary to what happens with primary teachers (34.0\%). Despite the high percentage of primary teachers who reported using them monthly, the majority (56.6\%) stated that they use them weekly, with only $9.4 \%$ of primary teachers reporting using books daily (see Graph 1 ).

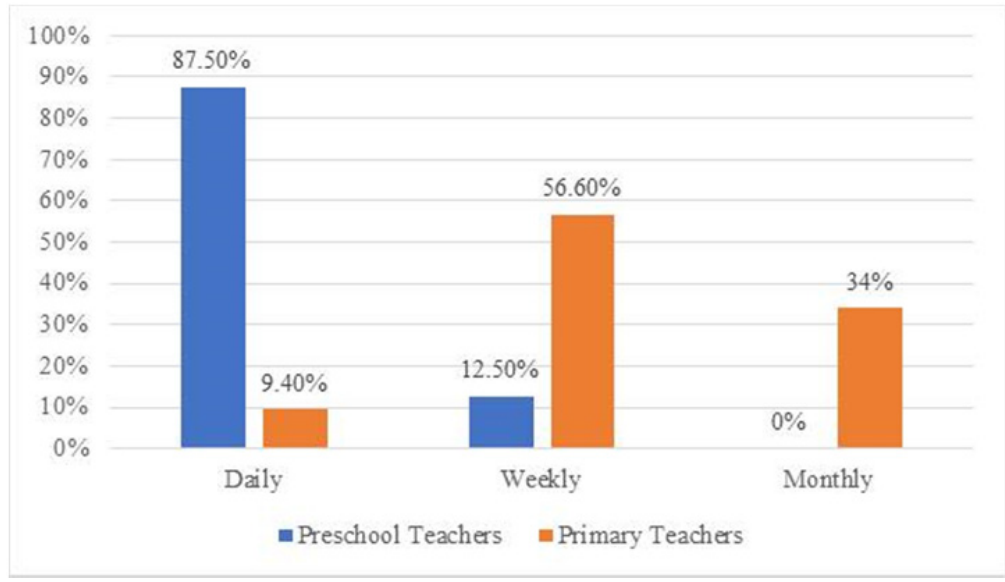

Graph 1. Frequency with which children's literature books are used

Regarding the regularity with which books are changed, according to the data depicted in Graph 2, we can see that both preschool and primary teachers report doing so "monthly", with $45.8 \%$ and $71.7 \%$, respectively. Daily book changes are only referenced by $4.2 \%$ of preschool teachers, $12.5 \%$ said that they never do it and $25 \%$ said that they do it weekly. In the case of primary teachers, $17 \%$ reported that they change them weekly. It should be noted that $11.3 \%$ of primary teachers and $12.5 \%$ of preschool teachers did not answer this question.

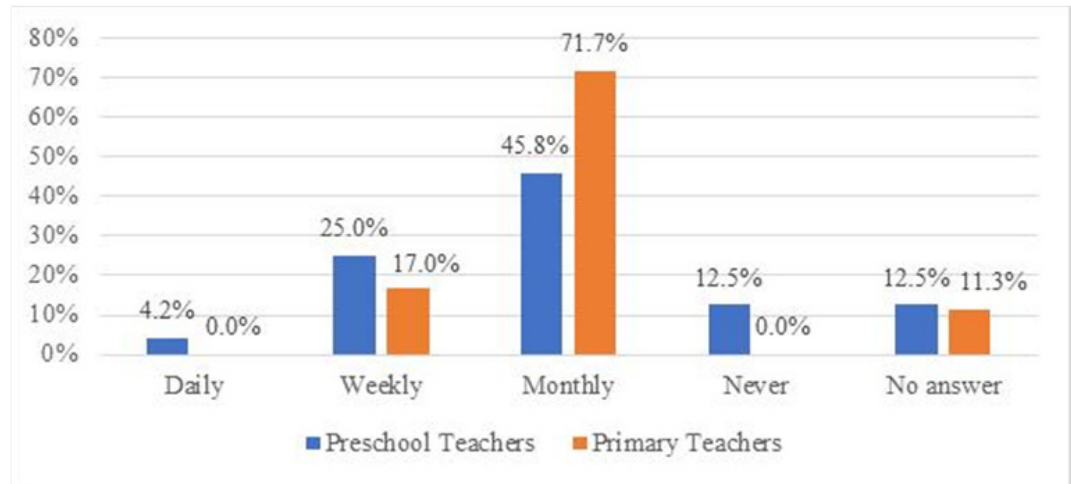

Graph 2. Regularity with which books are changed 
When asked how often they promote activities of the library area, preschool teachers revealed that they do it more often (66.7\% report doing it daily and 33.3\% weekly). As for primary teachers, only $1.9 \%$ said that they do it daily and another $1.9 \%$ stated that they never to do it, and most of them $(58.5 \%)$ reported that they promote activities in this space weekly, whereas almost $38 \%$ said that they do it only monthly.

On the other hand, when analysing the regularity with which children go to the library area, $87.5 \%$ of the preschool teachers stated that children go to this space daily, whereas $8.3 \%$ revealed that children only do it once a week. For $4.2 \%$, their children only go to this space when there is some activity planned in it (see Graph 3).

In turn, the participant primary teachers showed greater variability in the answers. Thus, $30.2 \%$ stated that their students go to the library area daily, $28.3 \%$ answered that they go "once a week", $11.3 \%$ pointed out that they go sporadically and $30.2 \%$ reported that their students use this space only when there is some activity planned in it (see Graph 3).

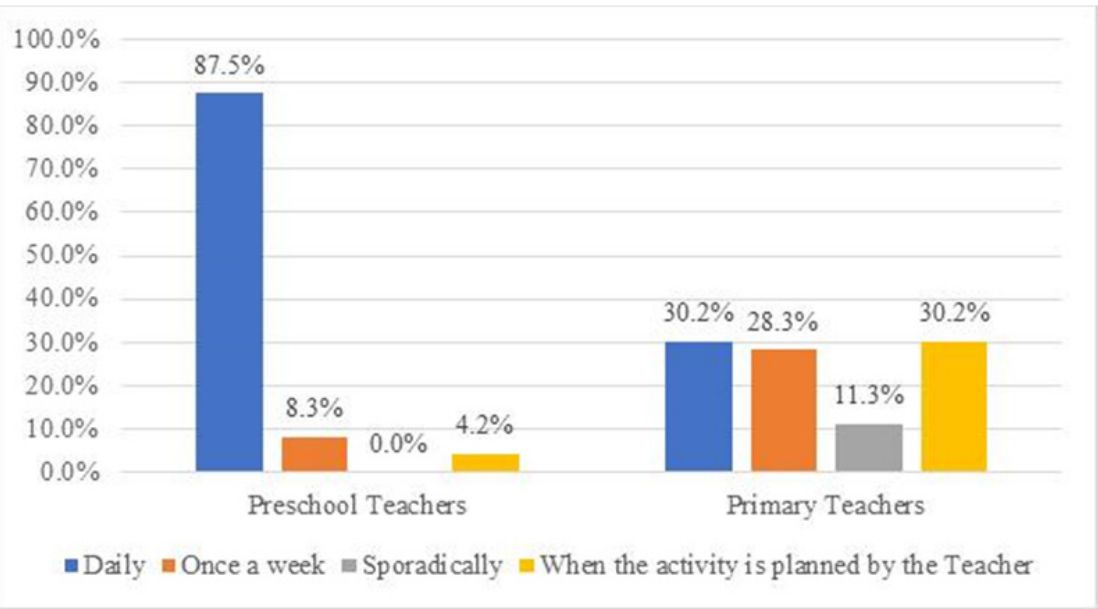

Graph 3. Regularity with which children use the library area

\subsubsection{The choice of children's literature books}

Regarding the criteria that are used by preschool and primary teachers in book selection, it was possible to identify three aspects deemed important: the valuation of the group of children and their needs and interests, the valuation of the book, and the documentation provided by higher-level entities.

Thus, in book selection, preschool teachers seem to ascribe higher importance to the topic to be addressed and the needs/interests of the group. In turn, primary teachers seem to value primarily the official documents (National and Regional Reading Plan and Curricular Goals), and then the needs/interests of the group.

Fourteen of the twenty-four preschool teachers $(58.3 \%)$ determined the theme as one of the criteria for selecting books, eleven (45.8\%) underlined the needs/interests of the group, eight (33.3\%) said that they also value the specificities of the book, seven $(29.2 \%)$ stressed that they take the age of the children into account and, finally, four (16.7\%) answered that they use the official documents to select the books to work on. Concerning primary teachers, thirty-two (6o.4\%) said that they chose the books according to the options put forth in the Curricular Goals, in the National and Regional Reading Plans, nineteen (35.8\%) said that they select them according to the students' needs/interests, eleven (20.8\%) reported that they take the age group into account, nine (17.0\%) highlighted the 
syllabus and four (7.5\%) highlighted the specificities of the books as one of the criteria they are based on.

\subsubsection{Comments}

Finally, and as the questionnaire provided a space for comments, respondents took the opportunity to express their dissatisfaction with the extension of the Portuguese program and the lack of resources in schools, stating that the competent Ministry should focus more on equipping of the rooms with books. Of the twelve preschool teachers who filled this space, six highlighted these aspects and, of the eighteen teachers, eleven also highlighted it. Furthermore, one teacher also pointed out that it would be important to have some training on how to select quality books. The remaining participants indicated some reading projects that they promote in their activities' room/classroom or stated that it would be critical to implement new projects.

\section{Discussion and Conclusions}

Based on the results attained through the questionnaires, we can state that all respondents value children's literature in the way they think about their pedagogical practice, considering the competences that it allows to develop, essentially, as a factor that fosters the development of orality and writing, as a knowledge vehicle and as an element that enhances creativity. The questionnaires also reveal that preschool teachers claim that they use children's literature most often.

Judging by the answers given, preschool children who enjoy the most reading spaces in the activities' room. In the primary education, besides the fact that not all teachers organise a space devoted to this purpose, many place books on a shelf in a classroom closet. According to Balça (2011), this strategy is not the best bet in pedagogical terms, and children must have a reading area where they can handle and explore books according to their tastes.

Even though in primary education, the organisation of the reading space of the classroom does not have a marked presence, it seems that there is, in both contexts, diversity of supports that allow children to contact with different structures and writing content. Therefore, in preschool education, the presence of thematic books, newspapers and magazines, and children's literature books is claimed to be very frequent, and the same happens in the primary education, which still gives prominence to dictionaries. It remains to be seen whether materials such as newspapers and magazines are indeed used by preschool and primary teachers as reading material, given that they are used for other purposes on many occasions, as revealed by the work of Santos (2007).

Anyhow, it should be pointed out that both preschool and primary teachers seem to ascribe importance to a set of criteria that should prevail in the organisation of the space devoted to reading. Thus, they expose the books so that children can see the covers - which is very important especially for pre-schoolers - and diversify the books, which they claim are sufficient for the number of children in the classrooms. The existing books have diverse sizes and formats and are directed to different levels of development, as proposed by Cerrillo (2006). According to Mata (2008), the organisation of the educational environment is central for the promotion of learning in children, and these aspects of selection and organisation of writing supports are a fundamental element arise children's interest in them (Santos, 2007; Hayes, 2016).

If the organisation of the educational environment is a critical component of the pedagogical intervention, the way space and materials are used and intentionally mobilised by the preschool and primary teacher is the key to children's development and learning.

Within this scope, preschool teachers seem to be more alert to the selection of reading materials that meet the needs and interests of children and the features of the age group, as suggested by Morrow and Gambrell (1998), Rueda (1995) or Hayes (2016). For primary teachers, the choice has a more normative nature, and they use the Regional or National Reading Plan and curriculum goals as instruments that dictate what should be read. 
Also in terms of pedagogical intervention strategies, results allow realising that if everyone claims to use the book and children's literature in their pedagogical practices when analysing their discourse in more detail, it is possible to identify clear differences between both contexts. These differences are evident, from the outset, in the frequency with which they use them. Indeed, while this is a daily practice in almost all preschool activities' room, it is much more spaced out in primary school classrooms. These disparities are also felt in terms of the regularity with which children choose the classroom library area, which occurs daily in preschool education and infrequently in the primary education, largely because of the lack of appropriate and equipped space, as the teachers themselves stress.

The differences are also evident in the regularity with which library area books are changed, with preschool teachers doing so more often than primary teachers. Here we must highlight the words of Balça (2011), when the author warns of the need to renew books in these spaces, given that, with this change, children feel more curious and willing to explore new works.

In summary, it seems to be true that preschool and primary teachers value children's books and literature but, in practice, preschool teachers seem to design and implement a higher number of pedagogical strategies that lead children to have a more regular contact with reading, and they promote a more comprehensive approach in terms of quality, as sustained by Colomer (2002), Tejerina Lobo (2004) and Silva (2013). In general, preschool teachers meet what Bento and Balça (2016) advocate - reading enjoyment as one of the principles of literary education -, using the book not as a privileged instrument for the content attainment but rather as a playful and pleasurable source.

As in any research work, the limitations of this study were felt, from the outset, in the need to confront the respondents' statements with their pedagogical practices, seeking to attain a closer reading of reality. As noted by Santos (2007), conceptions and pedagogical practices have often discontinuities that distance what teachers think from what, in the classroom practice, is carried out. Furthermore, there is the need to extend this study to a larger number of respondents, also including the children from these rooms, seeking to understand how they perceive the space where they act and what are their contributions to a better organisation of the reading spaces.

\section{References}

Alves Martins, M., \& Niza, I. (1998). Psicologia da aprendizagem da língua escrita [Psychology of written language learning]. Lisboa: Universidade Aberta.

Azevedo, F. (2006). Literatura infantil: Receção leitora e competência literária [Children' literature: Reading reception and literary competence]. In F. Azevedo (Coord.), Língua materna e literatura infantil. Elementos nucleares para professores do Ensino Básico [Native language and children's literature. Core elements for Basic Education teachers] (pp. 1-10). Lisboa: Lidel.

Balça, A. (2011). Vamos à biblioteca! - O papel da biblioteca escolar na formação de crianças leitoras [Let's go to the library! - The role of the school library in the development of reading children]. Nuances: Estudos sobre Educação, 13(14), 207-220. São Paulo. Available at http://revista.fct.unesp.br/index.php/Nuances/article/ viewFile/379/414.

Bento, I., \& Balça, A. (2016). Educação literária: Um estudo no pré-escolar e no 1.o ciclo do ensino básico [Literary education: A study in preschool and primary education]. Cadernos de Letras da UFF Dossiê: A crise da leitura e a formação do leitor, 52, 81-100. Niterói: Universidade Federal Fluminense.

Bingham, G. E., \& Hall-Kenyon, K. M. (2013). Examining teachers' beliefs about and implementation of a balanced literacy framework. Journal of Research in Reading, 36(1), 14-28. DOI: 10.1111/j.1467-9817.2010.01483.x.

Bogdan, R., \& Biklen, S. (1994). Investigação qualitativa em educação: Uma introdução à teoria e aos métodos [Qualitative research in education: An introduction to theory and methods]. Porto: Porto Editora.

Brown, R., Scull, J., Nolan, A., Raban, B., \& Deans, J. (2012). Young learners: Mapping the beliefs and practices of preschool teachers in relation to early literacy development. Australian Educational Research, 39, 313-331. DOI: 10.1007/s13384-012-0061-o. 
Cerrillo, P. (2006). Literatura infantil e mediação leitora [Children's literature and reading mediation]. In F. Azevedo (Coord.), Língua materna e literatura infantil - Elementos nucleares para professores do Ensino Básico [Native language and children's literature. Core elements for Basic Education teachers]. Lisboa: Lidel.

Chambers, A. (1996). The reading environment: How adults help children enjoy books. Maine: Stenhouse Publishers.

Colomer, T. (2002). Una nueva crítica para el nuevo siglo [A new critique for the new century]. CLIJ, $145,7-17$.

Dynia, J. M., Schachter R. E., Piasta, S. B., Justice, L. M., O’Connell, A. A., \& Pelatti, C. Y. (2018). An empirical investigation of the dimensionality of the physical literacy environment in early childhood classrooms. Journal of Early Childhood Literacy, 18(2), 239-263.

Gómez, G., Flores, J., \& Jiménez, E. (1996). Metodología de la investigación cualitativa Methodology of qualitative research]. Málaga: Ediciones Aljibe.

Guo, Y., Justice, L. M., Kaderavek, J. N., \& McGinty, A. (2012). The literacy environment of preschool classrooms: Contribution to children's emergent literacy growth. Journal of Research in Reading, 35(3), 308-327. DOI: 10.1111/j.1467-9817.2010.01467.x.

Hayes, C. (2016). Language, literacy \& communication in the early years. Northwich: Critical Publishing.

Levitt, R., \& Red Owl, R. H. (2013). Effects of early literacy environments on the reading attitudes, behaviours and values of veteran teachers. Learning Environments Research, 16(3), 387-409. DOI: 10.1007/s10984-013-9140-z.

Lim, C. (2010). Understanding Singaporean preschool teachers' beliefs about literacy development: Four different perspectives. Teaching and Teacher Education, 26, 215-224.

Mata, L. (2008). A descoberta da escrita: Textos de apoio para educadores de infância [The discovery of writing: Supporting texts for preschool teachers]. Lisboa: Ministério da Educação.

Mergulhão, T. (2011). Literatura infantil e a técnica do voo [Children's literature and the flight technique]. PROFFORMA, 03, 1-2.

Morrow, L. M. (1982). Relationships between literacy programs, library corner design, and children's use of literature. Journal of Educational Research, 75, 339-344.

Morrow, L. M., \& Gambrell, L. B. (1998). How do we motivate children toward independent reading and writing? In S. B. Neuman, \& K. A. Roskos (Eds.), Children achieving. Best practices in early literacy (pp. 144-161). USA: International Reading Association.

Morrow, L. M., \& Weinstein, C. S. (1982). Increasing children's use of literature through program and physical design changes. The Elementary School Journal, 85, 133-137.

Palo, M. \& Oliveira, M. (1992). Literatura infantil - Voz de criança [Children's literature - Children's voice] $\left(2^{\text {nd }}\right.$ ed.). São Paulo: Editora Ática.

Rueda, R. (1995). La biblioteca de aula infantil - El cuento y la poesía [The children's classroom library - Tale and poetry]. Madrid: Narcea.

Santos, A. I. (2007). A abordagem à leitura e à escrita no jardim-de-infância: concepções e práticas dos educadores de infância [The approach to reading and writing in preschool: Conceptions and practices of preschool teachers]. Unpublished PhD thesis. Ponta Delgada: University of The Azores.

Sénéchal, M. (2006). Reading books to young children: What it does and doesn't do. L1 - Educational Studies in Language and Literature, 6(3), 23-35.

Silva, M. T. (2013). Literatura para crianças e jovens. Da leitura dos livros à leitura do mundo. [Children's and youth literature. From reading books to reading the world]. In M. Madalena, T. Silva, \& I. M. González, Literatura para a infância e juventude e educação literária [Children's and youth literature and literary education] (pp. 32-51). Porto, Deriva.

Tejerina Lobo, I. (2004). El canon literario y la literatura infantil y juvenil. Los cien libros del siglo XX [The literary canon and children's and youth literature. The hundred books of the twentieth century]. Lazarillo: Revista de la Asociación de Amigos del Libro Infantil y Juvenil, 12, 17-25. ISSN: 1576-9666. Available at http://www.cervantesvirtual.com, 1-7. Accessed on February 3, 2009.

Terwagne, S. (2006). Read-alouds in kindergarten classrooms and the nature of literary understanding. L1 Educational Studies in Language and Literature, 6(3), 73-85.

Wray, D., Medwell, J., Fox, R., \& Poulson, L. (2000). The teaching practices of effective teachers of literacy. Educational Review, 52(1), 75-84. 